Marquette University

e-Publications@Marquette

$2-1-2018$

\title{
Quitting the Boss? The Role of Manager Influence Tactics and Employee Emotional Engagement in Voluntary Turnover
}

Christopher S. Reina

Virginia Commonwealth University

Kristie M. Rogers

Marquette University, kristie.rogers@marquette.edu

Suzanne J. Peterson

Arizpna State University Thunderbird School of Global Management

Jrus Byron

Georgia State University

Peter W. Hom

Georgia State University

Accepted version. Journal of Leadership \& Organizational Studies, Vol. 25, No. 1 (February 1, 2018):

5-18. DOI.@ 2018 SAGE Publications. Used with permission. 
Marquette University

\section{e-Publications@Marquette}

\section{Management Faculty Research and Publications/College of Business Administration}

This paper is NOT THE PUBLISHED VERSION; but the author's final, peer-reviewed manuscript.

The published version may be accessed by following the link in the citation below.

Journal of Leadership and Organizational Studies, Vol. 25, No. 1 (2018): 5-18. DOl. This article is

(C) SAGE Publications and permission has been granted for this version to appear in ePublications@Marquette. SAGE Publications does not grant permission for this article to be further copied/distributed or hosted elsewhere without the express permission from SAGE Publications.

\section{Quitting the Boss? The Role of Manager Influence Tactics and Employee Emotional Engagement in Voluntary Turnover}

Christopher S. Reina

Virginia Commonwealth University, Richmond, VA, USA

Kristie M. Rogers

Marquette University, Milwaukee, WI, USA

Suzanne J. Peterson

Arizona State University , Thunderbird School of Global Management, Glendale, AZ, USA

Kris Byron

Georgia State University , Atlanta, GA, USA

Peter W. Hom

Arizona State University, Tempe, AZ, USA 


\section{Table of Contents}

Manager Influence Tactics and Voluntary Employee Turnover............................................................ 4

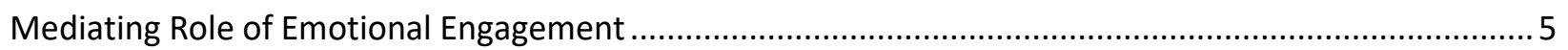

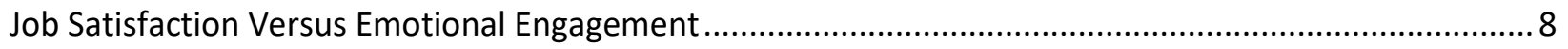

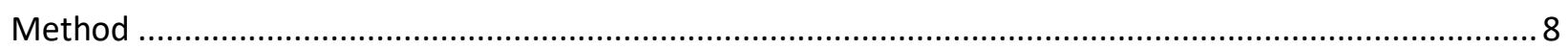

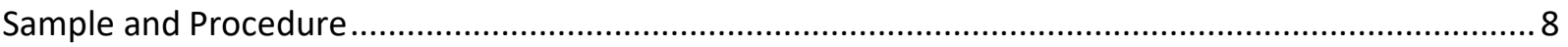

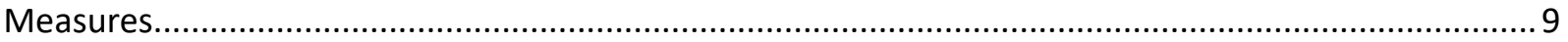

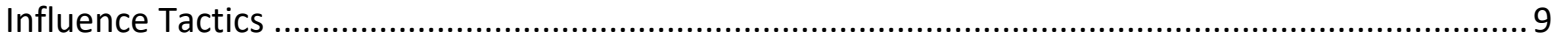

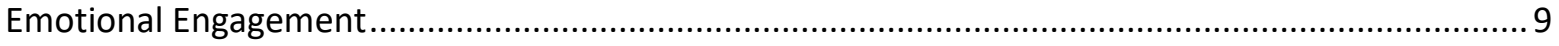

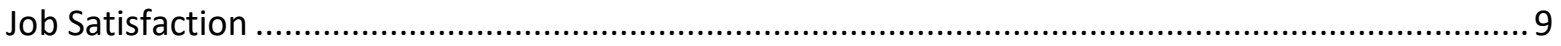

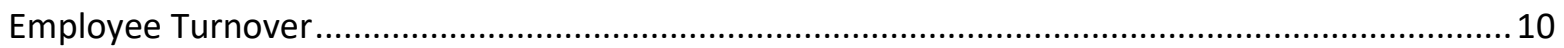

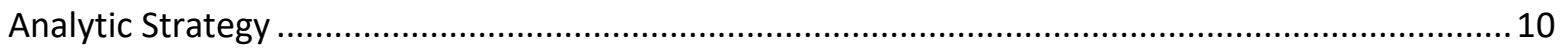

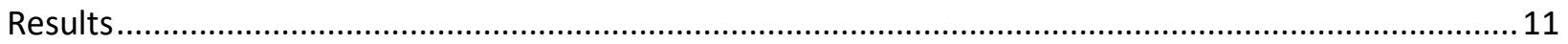

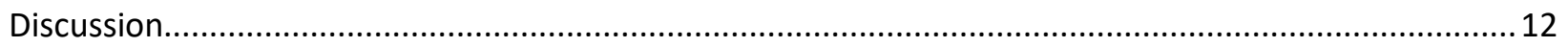

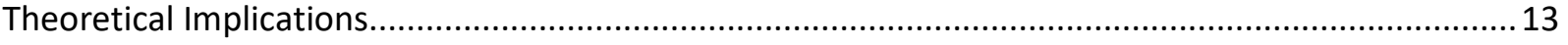

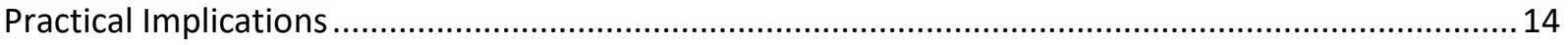

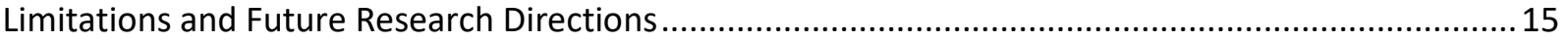

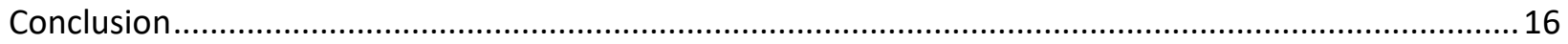

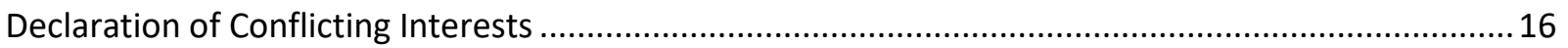

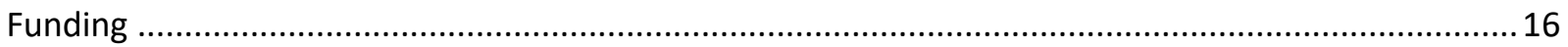

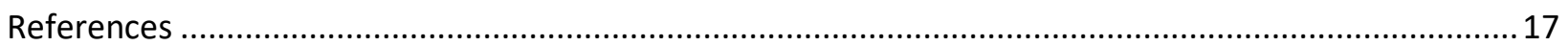

"When I turned in my letter, [the manager] said he was surprised and wanted to know what it would take to make me stay," says Anna. "I said that the working conditions were not conducive to effective performance, because I couldn't say the truth - that he made us all miserable. So two days later, he comes back with a new offer. I could have more money or fewer hours, but nothing else was any different. It's still the same toxic atmosphere." (An employee discussing her resignation in Robinson, 2008, p. 1)

Retaining valued employees remains one of the most pressing managerial challenges today. Estimates suggest that the total costs associated with turnover can range from $90 \%$ to $200 \%$ of annual salary due to recruitment, selection, and training expenses (Boushey \& Glynn, 2012; Cascio, 2015). Contributing to these costs, turnover often results in lost tacit knowledge, fewer seasoned mentors, work disruptions, damaged client relationships due to discontinuity, and an overall reduction in organizational 
effectiveness (Allen, Bryant, \& Vardaman, 2010; Eckardt, Skaggs, \& Youndt, 2014; Heavey, Holwerda, \& Hausknecht, 2013; Holtom, Mitchell, Lee, \& Eberly, 2008). Managers are thus motivated to learn why employees voluntarily leave their jobs and how they can prevent this loss (Holtom et al., 2008; Ulrich \& Smallwood, 2006). Ironically, as suggested by the opening quote, their behaviors may be the very reason that employees choose to leave. For example, in a survey of 10,000 job seekers, $42 \%$ left their jobs due to dissatisfaction with managers (Bhattacharya, 2008). Similarly, statistics show that $35 \%$ of senior executives blame unhappiness with management as the main cause of top performer turnover ("Survey: Bad Managers," 2009). As a result of such studies, the business press increasingly tells managers: "If you want to keep the most talented members of your team, it's time you start looking in the mirror and realize the biggest reasons why people quit have to do with you" (E. Jackson, 2014).

Although even the earliest formal turnover model (March \& Simon, 1958) specified how management practices that interfere with employees' autonomy increase their desire to leave, scholarly research rarely sustains widespread claims that managerial behavior greatly influences turnover (Ballinger, Lehman, \& Schoorman, 2010; Fleishman, 1998; K. J. Harris, Wheeler, \& Kacmar, 2009). In particular, traditional turnover research finds that how followers feel about their leaders, which is largely captured through leader-member exchange (LMX) and satisfaction with supervisor, typically explains less than $10 \%$ of the turnover variance (Dulebohn, Bommer, Liden, Brouer, \& Ferris, 2012; Griffeth, Hom, \& Gaertner, 2000; Rubenstein, Eberly, Lee, \& Mitchell, 2017). Conceivably, the prevailing focus on relationship quality and leader satisfaction understates the influence managers can wield as they can discourage (or encourage) leaving in ways beyond social exchanges with employees. Accordingly, more recent studies suggest that the relationship between these variables is more complicated than previously thought (T. B. Harris, Li, \& Kirkman, 2014), which further emphasizes the need to take specific leader behaviors into account to understand their impact on follower outcomes such as turnover (e.g., see Schyns \& Schilling, 2013, for a meta-analysis on outcomes of destructive leader behaviors).

To extend turnover research, we investigate the effects of two specific downward influence tactics on employee retention. Long-standing research on downward influence tactics has shown that such behaviors can profoundly shape employees' attitudes (Falbe \& Yukl, 1992; Yukl \& Tracey, 1992), but how managers' use of these influence tactics can affect employee retention remains unexplored. As noted by Yukl, Seifert, and Chavez (2008), researchers should "directly probe the perceptual and motivational processes needed to explain how different tactics influence the attitudes and behaviors of target persons" (p. 618). From a practical standpoint, understanding how managerial influence tactics can affect employee turnover offers insight into how organizations can reduce costly and unwanted voluntary turnover, a particularly salient challenge to address as U.S. voluntary quits steadily increase, which as of 2016 approached prerecession numbers (Bureau of Labor Statistics, 2016; Hall, 2013).

Along with scant research on ways in which managers contribute to employee attrition, our understanding of the psychological mechanisms through which managers foster loyalty remains limited. Extant theoretical perspectives primarily assume that managers encourage employees to stay by prompting favorable attitudes toward the overall job or themselves (Mobley, Griffeth, Hand, \& Meglino, 1979; Price \& Mueller, 1986; Rusbult \& Farrell, 1983). Yet managers might induce other affective mechanisms, such as moods (George \& Jones, 1996) and emotions (Kahn, 1990) that employees experience over time, which contribute to their overall sense of affective engagement at work. Metaanalytic results (e.g., Harter, Schmidt, \& Hayes, 2002) as well as longitudinal evidence (Harter, Schmidt, Asplund, Killham, \& Agrawal, 2010) suggest that managers' actions shape employees' perceptions and 
attitudes, which, in turn, drive important outcomes such as collective turnover. Their behaviors may occasion "shocks" - crucial events prompting employees to think about leaving (e.g., negative performance review, promotion denial; Burton, Holtom, Sablynski, Mitchell, \& Lee, 2010), diminishing their engagement (Kahn, 1990) and causing them to quit (independently of job attitudes; Lee \& Mitchell, 1994; Lee, Mitchell, Holtom, McDaniel, \& Hill, 1999; Lee, Mitchell, Wise, \& Fireman, 1996). This suggests that managers' behaviors, such as their use of influence tactics, may increase or decrease employee engagement through the introduction of shocks that play an important role in determining whether employees quit, despite their generally positive job attitudes (Burton et al., 2010; Lee et al., 1996).

In summary, our inquiry contributes to the scholarly literature in several ways. First, we expand the scope of leader-driven follower turnover by scrutinizing how managers' use of two specific influence tactics can affect employees' loyalty. All too often, turnover researchers have focused on employees' affect toward managers or quality of relationships with managers (Dulebohn et al., 2012; Griffeth et al., 2000; Rubenstein et al., 2017), overlooking how managers' behaviors translate into followers' affective reactions. We investigate how managerial influence tactics affect employee turnover, as past research has primarily assessed their impact on employee compliance or managerial effectiveness (Yukl, Chavez, \& Seifert, 2005; Yukl et al., 2008). By doing so, we provide a missing link in both research streams, while yielding practical insight into how managers can secure job loyalty and helping answer the question of whether employees do indeed leave their managers. Second, we identify emotional engagement as a key mechanism for translating manager behaviors onto employee attrition over and above job satisfaction (Mobley et al., 1979; Price \& Mueller, 1986), thus reinforcing the significance of affective states (Brief \& Weiss, 2002) in the turnover process. This is significant considering that affective states are downplayed in contemporary views on turnover and retention (notably, the unfolding model and job embeddedness theory; Lee \& Mitchell, 1994; Mitchell \& Lee, 2001). Importantly, our approach aligns with recent demonstrations that affect and emotions operate in tandem with influence tactics to determine leader effectiveness (cf. Griffith, Connelly, Thiel, \& Johnson, 2015).

\section{Manager Influence Tactics and Voluntary Employee Turnover}

Though research has found modest leadership effects on employee attrition (Cotton \& Tuttle, 1986; Dulebohn et al., 2012; Griffeth et al., 2000; Rubenstein et al., 2017), managers' use of influence tactics toward employees may reveal stronger attrition effects (Yukl, 2010). Downward influence tactics refer to leaders' attempts to motivate followers to carry out their requests (Yukl, Kim, \& Falbe, 1996). Because previous work suggests that different tactics yield different outcomes (Falbe \& Yukl, 1992; Yukl et al., 1996; Yukl \& Tracey, 1992), we focus on two downward tactics that most likely impact employee decisions to leave or stay and operate specifically through affective mechanisms (1) pressure (i.e., demands, threats, or persistent reminders to control employee behavior) and (2) inspirational appeals (i.e., explicit appeals to employees' values, goals, and aspirations). We scrutinize these two tactics for several reasons. First, past research indicates that pressure and inspirational appeals are commonly used in downward directions (Kipnis, Schmidt, \& Wilkinson, 1980; Yukl et al., 2005; Yukl \& Falbe, 1990). Second, they generate opposing effects on influence targets' affect, motivation, and behavior: "soft" tactics (e.g., inspirational appeals) generally elicit positive emotions and commitment, while "hard" tactics (e.g., pressure) generally induce negative emotions and resistance (Falbe \& Yukl, 1992; Yukl \& Tracey, 1992). Finally, these tactics reflect divergent leader behaviors. Abusive or autocratic managers 
often use pressure tactics, whereas transformational leaders primarily deploy inspirational appeals (Bass, 1985; Zellars, Tepper, \& Duffy, 2002).

We expect that employees will more likely leave their organization when managers use hard pressure tactics to influence them. Current theory and research suggest that pressure is often viewed as an abusive (Zellars et al., 2002), autocratic (Judge, Piccolo, \& Ilies, 2004), or oppressive use of power (Ashforth, 1994). When employees are treated in an uncivil or disrespectful manner, they may consider leaving to avoid future mistreatment (Pearson \& Porath, 2005). Also, when employees feel abused by an authority figure, they experience anger, fear, and work alienation (Ashforth, 1994). Such reactions are likely distracting and can deplete their emotional resources. Employees also strive to regain a sense of emotional control by distancing themselves from the negative behavior and its source (Frijda, 1986). This distancing from the manager likely translates into greater feelings of detachment from the organization (Kahn, 1990) and may ultimately lead to turnover behavior.

In contrast, we expect that managers' use of soft inspirational appeals to influence employees will reduce their desire to leave the organization. Such tactics emphasize employees' values, ideals, and aspirations, thereby arousing their enthusiasm and confidence (Yukl \& Falbe, 1990). Managers' inspirational appeals can motivate employees to stay for several reasons. First, inspirational appeals can increase the perceived meaningfulness of employees' jobs. By explaining how meeting their requests would serve employees' ideals or larger organizational mission, managers elevate employees' perceptions of the requested task's significance, and by generalization, the overall significance of their role (Grant \& Sumanth, 2009). In addition, inspirational appeals often promise more developmental opportunities when managers exhort employees "to excel, to beat competitors, or accomplish an important, challenging task" (Yukl \& Falbe, 1990, p. 133). To achieve lofty goals, managers may expand employees' job responsibilities, while instilling confidence in their ability to grow and develop at work. Greater intrinsic job rewards-derived from increased meaningfulness and developmental opportunities-in turn, reinforce employees' likelihood of staying (via higher need-supply job fit or job enrichment; McEvoy \& Cascio, 1985; Mitchell \& Lee, 2001). Second, inspirational appeals enhance experienced positive emotions at work by arousing enthusiasm (Falbe \& Yukl, 1992; Yukl \& Tracey, 1992), thus sustaining resource conservation and avoiding the negative effects of resource depletion, which may ultimately result in an employee leaving the organization (Chau, Dahling, Levy, \& Diefendorff, 2009; Lapointe, Vandenberghe, \& Panaccio, 2011). Thus, managers' use of inspirational appeal is likely to decrease turnover.

Based on the aforementioned arguments regarding how managerial pressure and inspirational appeals can affect employee turnover, we propose the following:

Hypothesis 1: Managers' influence tactics are related to employee turnover, such that (a) managerial pressure is positively related to employee turnover and (b) managerial inspirational appeal is negatively related to employee turnover.

\section{Mediating Role of Emotional Engagement}

Prior research indicates a causal relationship between actions and behaviors of managers and organizational outcomes such as turnover and employees' attitudes, including engagement, that mediate this causal relationship (Harter et al., 2010). We focus on managerial action in the form of influence tactics, specifically examining how pressure and inspirational appeals affect employee 
turnover through employee emotional engagement-a motivational state reflecting how intensely and persistently employees emotionally invest themselves in their roles (Kahn, 1990). Though job engagement also involves cognitive and physical components (Kahn, 1990), we focus on emotional engagement because this dimension captures an affective experiental state (Judge, Weiss, KammeyerMueller, \& Hulin, 2017) overlooked by the focus on attitudinal evaluative judgments in many turnover investigations (Griffeth et al., 2000; Hom, Lee, Shaw, \& Hausknecht, 2017). Cognitive engagement-the degree to which employees experience mental challenges from their role-and physical engagementthe level of personal resources an individual has available for role enactment-are thus outside the scope of previous turnover research, which largely emphasized the importance of affective processes (narrowly construed as attitudes; Judge et al., 2017) when accounting for follower turnover. Furthermore, a primary motivation of this study is to investigate the mediating effect of another affective mechanism above and beyond job satisfaction. Although job satisfaction and emotional engagement share significant conceptual overlap given their affective focus, contemporary views on affect distinguish between attitudes and emotions (Brief \& Weiss, 2002; Judge et al., 2017). We thus identify emotional engagement (as opposed to the other two types of engagement) as the most relevant mechanism to include for translating managerial behaviors onto employee attrition over and above job satisfaction. Additionally, emotional engagement most directly underlies the feeling and "connection" employees have toward their work and the people with whom they interact at work (Kahn, 1990; Rich, LePine, \& Crawford, 2010).

Below we articulate how emotional engagement may play a vital mediating role in transmitting the effects of leader influence tactics onto employee turnover. We first discuss how downward influence tactics affect emotional engagement by articulating how they invoke the three preconditions for engagement identified by Kahn (1990): meaningfulness, safety, and availability. Then, we discuss how emotional engagement in turn affects employee turnover.

The first precondition for emotional engagement is meaningfulness, which is the sense that one's efforts are directed toward fruitful endeavors and likely to reap high returns (Kahn, 1990). We suggest that through the use of inspirational appeals, managers can create a sense of meaningfulness, while the use of pressure tactics decreases employees' perceived meaningfulness of work. According to social information processing and job crafting perspectives (Salancik \& Pfeffer, 1978; Wrzesniewski \& Dutton, 2001), managers can provide employees with an inspiring vision of what their efforts can achieve and frame tasks as being challenging and worthy of investing time and energy (Yukl et al., 2008). Managers' inspirational appeals can also arouse employees' enthusiasm for the end result of the tasks at hand. For example, leaders use inspirational appeals to encourage followers to commit to desired collective goals and visions (Bass, 1985). In doing so, managers promote greater emotional engagement as employees emotionally invest themselves in performing meaningful tasks to achieve worthwhile goals (Yukl \& Tracey, 1992). On the other hand, managers who use pressure tactics attempt to influence employee behavior with threats and intimidation (rather than extol the worth of their demands), which likely reduce task meaningfulness given that employees perceive little control over directing their own efforts toward achieving goals important to them (Yukl \& Falbe, 1990). Thus, managers' inspirational appeals can increase employees' experienced meaningfulness, thus increasing emotional engagement, while managers' pressure tactics can decrease employees' experienced meaningfulness, thus decreasing emotional engagement. 
The second precondition for emotional engagement is "feeling able to show and employ one's self without fear of negative consequences" (Kahn, 1990, p. 708) and emanates from interpersonal interactions that make individuals feel supported, trusted, and allowed to fail without reprimand. We posit that managerial pressure tactics erode safety because managerial actions such as constantly checking employees' progress or threatening sanctions if employees fail to comply (Yukl et al., 2008) convey to employees that it is unsafe to freely express opinions and emotions without negative repercussions. Previous leadership research on pressure tactics suggest that these tactics undermine psychological safety by demonstrating disrespect for followers' opinions and values (Russell \& Stone, 2002). On the other hand, managers' use of inspirational appeals instills confidence and enthusiasm in followers by appealing to their values and giving them the space to act according to these values, which enhances feelings of safety at work (Yukl \& Falbe, 1990). In sum, we suggest that managerial pressures diminish employees' felt safety, which in turn, lowers their emotional engagement, while managerial inspirational appeals increase employees' felt safety, which increases emotional engagement.

The third precondition for emotional engagement is availability of resources. The energy and resources employees need to emotionally engage are available when they are not distracted by frustration, excessive demands, or insecurity, which generally arise from poor interpersonal interactions (Kahn, 1990). Both inspirational appeals and pressure from managers affect followers' availability of emotional resources. Specifically, because inspirational appeals speak to employees' values and aspirations and increase confidence, they boost resource availability by arousing positive emotions (Falbe \& Yukl, 1992). Conversely, pressure tactics reduce resource availability by creating excessive demands and stress as employees perceive pressure tactics as inconsiderate, which can lessen their positive affect and motivation (Judge et al., 2004). In support, empirical studies find that managers who coerce performance diminish employees' contentment and happiness, while arousing their anger and resentment (Sparrowe, Soetjipto, \& Kraimer, 2006). In sum, manager influence tactics affect employees' emotional engagement by either building emotional resources through inspirational appeals or by depleting such resources through the use of pressure tactics.

Theory and research suggest that employee engagement may affect important business outcomes such as turnover (Harter et al., 2002). As Kahn (1992) explains, when employees fail to emotionally engage, they become pessimistic, unhappy, and cynical about their work roles. In addition, because they feel less safe and less emotionally available, they struggle to connect with others, thereby experiencing a lack of fit in their roles (Kahn, 1990). The idea that employee emotional engagement predates or culminates in turnover is consistent with various viewpoints on job detachment, withdrawal progression, and conservation of resources. In particular, Burris, Detert, and Chiaburu (2008) maintain that employees who are psychologically detached from organizations increasingly shed "their personal engagement with, or psychologically separate themselves from their involvement in, the organization" (p. 914). They become emotionally disengaged and "psychologically quit" before physically leaving the job (Greenhalgh, 1980). Additionally, withdrawal-of-progression models imply that employees who are less emotionally engaged in their jobs increasingly withdraw from work and eventually quit (Harrison, Newman, \& Roth, 2006; Hom \& Kinicki, 2001). Furthermore, conservation of resources formulations posit that employees' depletion of emotional resources induce emotional exhaustion, making employees liable to exit to restore their resources (Wright \& Cropanzano, 1998). On the other hand, when work replenishes emotional resources (Kahn, 1990), individuals feel the opposite emotions, such as enthusiasm and excitement (i.e., emotional engagement; Rich et al., 2010), making them less quit- 
prone. In support, Hallberg and Schaufeli (2006) report an inverse relationship between work engagement and quit intentions. Based on the above reasoning and empirical evidence as well as the logic presented in Hypotheses $1 \mathrm{a}$ and $1 \mathrm{~b}$, we propose that the influence tactics of pressure and inspirational appeals affect employee turnover and that emotional engagement mediates these relationships.

Hypothesis 2a: Managerial use of pressure tactics is positively associated with employee turnover through the mediated effect of employee emotional engagement.

Hypothesis 2b: Managerial use of inspirational appeals is negatively associated with employee turnover through the mediated effect of employee emotional engagement.

\section{Job Satisfaction Versus Emotional Engagement}

As articulated above, we expect emotional engagement to mediate the relationship between influence tactics and turnover. Rich et al. (2010) found that job engagement outperformed job satisfaction, job involvement, and intrinsic motivation in explaining the relationship between multiple antecedents and employee performance (both in-role and extra-role). However, given long-standing theory that job satisfaction is a primary mediator of leadership effects (March \& Simon, 1958; Mobley et al., 1979; Price \& Mueller, 1986), we also examine whether emotional engagement represents an independent source of transmitting the effects of managerial influence tactics on employee turnover over and above that of job satisfaction, which has been the traditional explanatory mechanism. Additionally, among the six best proximal predictors of turnover identified by Griffeth et al. (2000), job satisfaction is the only attitudinal predictor for which the job is the referent and is also the attitude most likely confounded with job engagement. Therefore, job satisfaction represents the most plausible competing explanation for how influence tactics impact turnover. In addition, given our focus on the emotional aspect of engagement, job satisfaction is most conceptually similar to emotional engagement given its affective focus (cf. Judge et al., 2017). Indeed, job satisfaction has been described as a "pleasurable or positive emotional state" by Locke (1976, p. 1300) and reflects affect toward superiors (Russell et al., 2004), while turnover and embeddedness scholars implicitly conflate all affective states (e.g., emotions, moods) with attitudes (cf. Lee \& Mitchell, 1994; Mitchell \& Lee, 2001). We thus include job satisfaction as well as emotional engagement to account for the relationship between manager influence tactics and follower turnover with the goal of assessing whether emotional engagement offers explanatory power over and above job satisfaction.

Hypothesis 3: Employee emotional engagement mediates relationships among influence tactics (pressure and inspirational appeals) and employee turnover over, and above job satisfaction when job satisfaction is included as an additional mediator.

\section{Method}

\section{Sample and Procedure}

To fill a conspicuous void in our understanding of voluntary executive turnover (Bauer, Erdogan, Liden, \& Wayne, 2006; Ou, Seo, Choi, \& Hom, 2016), we sought a sample of high-level employees whose supervising managers have considerable discretion over using influence tactics. The sample consisted of employees from the marketing division of a large financial services institution located in the northeastern United States. We chose the company's 126 directors for our employee sample because 
the nature of their work required daily exchanges and interactions with their superiors (a total of 41 vice presidents). Thirty-six directors were excluded from the final sample because they chose not to participate or did not complete all measures, leaving 90 directors (71\% response rate). On average, the directors were 34.4 years old and had 4.4 years of tenure; $79 \%$ were Caucasian and $59 \%$ were male.

On initial data collection, employees (directors) received an electronic questionnaire containing a cover letter from the researchers with an endorsement from the marketing division's executive vice president. We collected data on three different time periods to reduce common method bias (Podsakoff, MacKenzie, Lee, \& Podsakoff, 2003). In the Time 1 survey, employees responded to items regarding their managers' (vice presidents) use of influence tactics and described their job satisfaction and demographic background. Approximately 3 months later (Time 2), employees received another short electronic survey asking them to report emotional engagement in their jobs. Approximately 12 months later (Time 3), we collected the objective, voluntary turnover data for employees based on company records.

\section{Measures}

Influence Tactics

Employees described the extent to which their manager exhibited inspirational appeals and pressure toward them personally using items from Yukl et al.'s (2008) Influence Behavior Questionnaire. Specifically, employees described managerial pressure by responding to the following items: "My manager demands that I carry out his or her requests," "My manager uses threats or warnings when trying to get me to do something," "My manager repeatedly checks to see if I have carried out a request," and "My manager tries to pressure me to carry out requests." Employees responded with a scale ranging from 1 ( $\mathrm{He} /$ she very seldom uses this tactic with me) to 4 (He/she uses this tactic very often with me). Higher scores indicate managers' greater use of pressure tactics ( $\alpha=.91)$.

Employees also reported how often their managers used inspirational appeals by responding to the following items: "My manager says a proposed activity or change is an opportunity to do something really exciting and worthwhile," "My manager describes a clear, inspiring vision of what a proposed project or change could accomplish," "My manager talks about ideals and values when proposing a new activity or change," and "My manager makes an inspiring speech or presentation to arouse enthusiasm for a proposed activity or change." Employees responded using the same 4-point rating scale as for pressure tactics. Higher scores indicate more frequent use of inspirational appeals $(\alpha=.84)$.

\section{Emotional Engagement}

Emotional engagement was measured using the six items from emotional engagement subscale of Rich et al.'s (2010) job engagement scale. These items tap the degree of positivity and energy directed toward one's job. Employees rated their emotional engagement using a 5-point agree-disagree scale. Sample items included "I am enthusiastic in my job," "I am interested in my job," and "I feel positive about my job." Higher scores indicate more emotional engagement $(\alpha=.96)$.

\section{Job Satisfaction}

Three items from the Hackman and Oldham Job Diagnostic Survey (Hackman \& Oldham, 1975) measured overall job satisfaction. The items were "Generally speaking, I am very satisfied with my job," "I am generally satisfied with the feeling of worthwhile accomplishment I get from doing this job," and "I 
am generally satisfied with the kind of work I do in this job." Employee ratings ranged from 1 (strongly disagree) to 5 (strongly agree). Higher scale scores indicate higher job satisfaction $(\alpha=.89$ ).

\section{Employee Turnover}

Fifteen months after the first survey, we collected information from the organization about employees' employment status. Twenty-one employees had voluntarily quit in that timeframe (quit rate $=23.3 \%$ ).

\section{Control Variables}

Because prior research demonstrated that employees' gender and organizational tenure predict turnover (Hom, Roberson, \& Ellis, 2008; Rubenstein et al., 2017), failure to include these variables as controls could potentially bias regression results. We therefore included employee gender $(1=$ female, 2 $=$ male) and firm tenure as control variables in all statistical analyses.

\section{Analytic Strategy}

Because employees (directors) are nested within managers (i.e., 4-6 directors per vice president), we used Mplus 7 to test multilevel versions of the mediation models depicted in Figure 1. Moreover, we used the mean- and variance-adjusted weighted least squares estimator (WLSMV) in Mplus because our turnover variable was a skewed, dichotomous criterion (Bryne, 2012; Finney \& DiStefano, 2006). To control for measurement error (Cole \& Preacher, 2014), our models fixed each manifest variable to have a factor loading of 1 and an error variance equal to $(1-\alpha) \times$ the variable's variance.

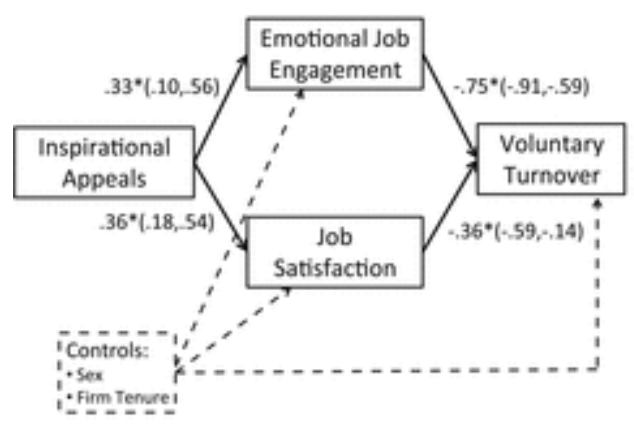

(a)

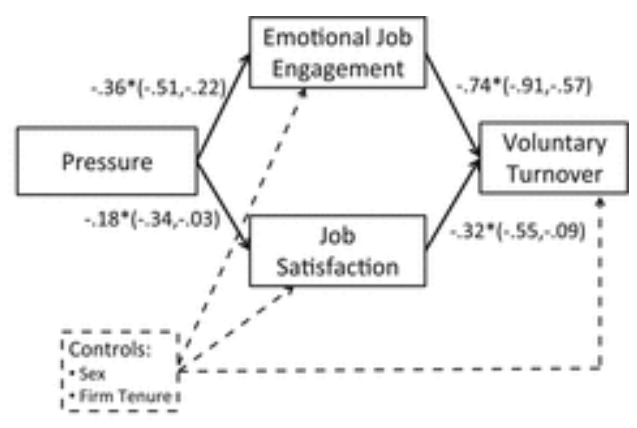

(b)

Figure 1. Full mediation models of influence tactics: (a) inspirational appeal model and (b) pressure model.

Note. Parameter estimates are standardized coefficients. Parentheses enclosed $95 \%$ confidence intervals for parameter estimates.

$* p<.05$.

To evaluate model fit, we interpreted the comparative fit index (CFI), the root mean square error of approximation (RMSEA), and standardized root mean square residual (SRMR). CFIs exceeding .90 indicate adequate fit (Hu \& Bentler, 1999). RMSEA of less than .05 indicate close fit, values between 05 and .08 indicate reasonable fit, and values between .08 and .10 indicate mediocre fit (Bryne, 2012). SRMR values less than .10 signal good fit (Kline, 2011). For WLSMV estimation, Mplus computes the weighted root mean square residual (WRMR) rather than SRMR; values below 1.0 represent good fit (Finney \& DiStefano, 2006; Yu, 2002). 
We additionally tested mediation in two ways. First, we compared nested models specifying full mediation (see Figure 1) and partial mediation (specifying a direct path from an influence tactic to turnover). For this purpose, we used Mplus's special $\chi 2$ difference testing as our models were estimated with WLSMV (Byrne, 2012; Muthén \& Muthén, 2012). Second, we used "biased-corrected bootstrapping," a nonparameteric resampling procedure to more accurately estimate (often nonnormal) sampling distributions of indirect effect estimates (Preacher \& Hayes, 2008). Simulation research shows that this approach is superior to the Baron-Kenny or Sobel methods for mediation testing when samples are small, outperforming them in statistical power and Type 1 error rates (Hayes, 2013; MacKinnon, Lockwood, Hoffman, West, \& Sheets, 2002).

We note that we tested unilevel models when comparing nested WLSMV models because bootstrapping and nested model testing with a dichotomous dependent variable is currently not available in Mplus 7. Nonetheless, intraclass correlations for endogenous variables (i.e., turnover, job satisfaction, emotional engagement) were all zero, indicating that between-group variance was nonexistent. That is, Level-1 differences within groups accounted for most response variance. Conceivably, such findings reflect our small Level-1 Ns as the average number of employees per manager was 3, although 30 individuals per group (and 30 groups) are historically prescribed for multilevel analyses (Maas \& Hox, 2005; Scherbaum \& Ferreter, 2009). High-level management teams, such as those represented in our study, are often small (Ou et al., 2016). That said, nonindependence of observations did not unduly bias our unilevel findings (see below).

\section{Results}

Table 1 reports correlations, means, and standard deviations for all variables. Inspirational appeal was positively related to job satisfaction and emotional engagement, while being inversely related to voluntary quit. In contrast, pressure tactics was negatively related to job satisfaction and emotional engagement but positively related to voluntary turnover. Inspirational appeal was also inversely related to pressure tactics.

\begin{tabular}{|c|c|c|c|c|c|c|c|c|}
\hline Variable & M & SD & 1 & 2 & 3 & 4 & 5 & 6 \\
\hline 1. Gender & 1.59 & 0.49 & & & & & & \\
\hline 2. Firm tenure & 4.37 & 2.26 & -0.105 & & & & & \\
\hline 3. Inspirational appeal & 3.05 & 0.77 & 0.021 & 0.199 & & & & \\
\hline 4. Pressure tactics & 2.54 & 0.90 & -0.002 & -0.155 & $-0.375^{* 4}$ & & & \\
\hline 5. Job satisfaction & 3.97 & 1.28 & 0.001 & 0.002 & $0.280^{\circ *}$ & -0.158 & & \\
\hline 6. Emotional engagement & 3.42 & 1.05 & -0.017 & 0.094 & $0.250^{*}$ & $-0.317^{k=1}$ & $0.255^{*}$ & \\
\hline 7. Voluntary tumover & 0.23 & 0.43 & 0.034 & -0.078 & $-0.313^{* *}$ & $0.254^{*}$ & $-0.359 \mathrm{ik}$ & $-0.704^{\mathrm{kik}}$ \\
\hline
\end{tabular}

Note. $N=90$. Gender is coded as I for women and 2 for men. Turnover is coded I for voluntary turnover and 0 for stayers. "p $<$. OS (two-taled). " $p<.01$ (ewo-tailed).

Table 2 reports fit statistics for various mediation models for how influence tactics affect voluntary employee turnover. Testing the inspirational appeal model in Figure 1a, Table 2 reports excellent or good fit statistics for CFI, SRMR, and WRMR for Model 1 (i.e., "multilevel full mediation model"), while uncovering an RMSEA (.069) indicative of "reasonable fit." According to standardized parameter estimates in Figure 1a, higher levels of inspirational appeals correspond with lower levels of voluntary turnover among employees through higher levels of felt emotional job engagement and job satisfaction. Verifying this mediation, Table 3 indicates that 95\% bias-corrected bootstrapped confidence intervals omitted zero for separate mediational pathways via emotional engagement and job satisfaction, while 
also omitting zero for total indirect effects. However, Table 2 indicates that the full mediation model (Model 3) fit data marginally worse than the partial mediation model (Model $2: \chi^{2}=3.428, p<.10$ ).

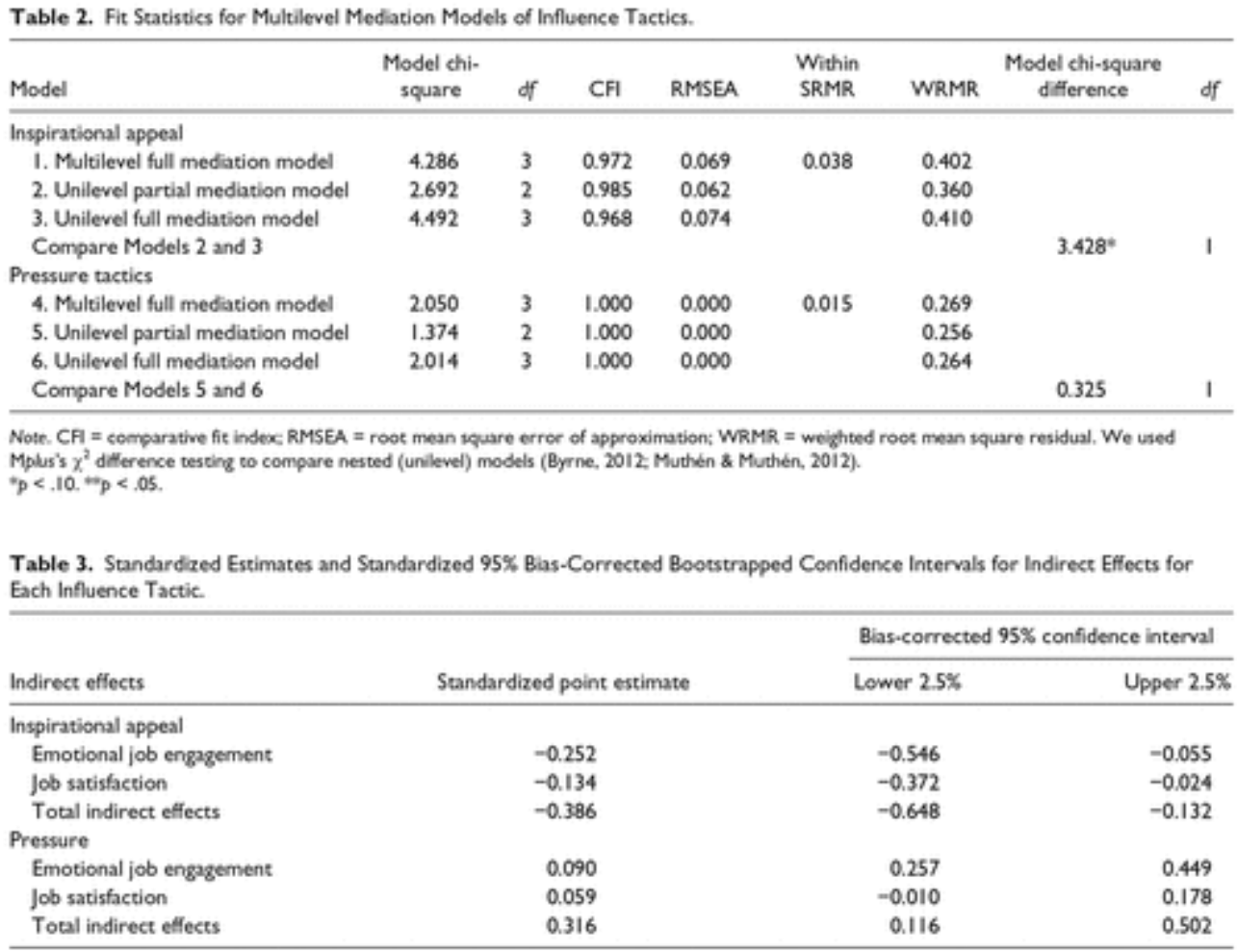

Note. Escimates derived frem unlevel full-mediation model controlling for measurement error.

Table 2 further sustains the pressure-tactics mediation model in Figure $1 \mathrm{~b}$, uncovering good to excellent fit indices for Model 4-the "multilevel full mediation model." According to Figure $1 \mathrm{~b}$ parameter estimates, higher levels of pressure tactics correspond with higher levels of voluntary turnover among employees through lower levels of experienced emotional job engagement and job satisfaction. Sustaining full mediation, Table 3 reports $95 \%$ bias-corrected bootstrapped confidence intervals that omit zero for the indirect effect via emotional engagement and the total indirect effect. However, the confidence interval for the indirect effect through job satisfaction did include zero, disputing its mediational role. Further upholding full mediation, Table 2 indicates no statistical difference $(\chi 2=.325$, $p>.10$ ) between the full and partial mediation models (i.e., Models 5 and 6), revealing no unmediated direct path from pressure tactics to voluntary attrition.

\section{Discussion}

Our study extends previous research in the areas of turnover (Lee \& Mitchell, 1994; Mitchell \& Lee, 2001), influence tactics (Falbe \& Yukl, 1992; Yukl et al., 2008; Yukl \& Tracey, 1992), and leader influence (Bass, 1985; Judge et al., 2004; Zellars et al., 2002) by adopting an engagement perspective (Kahn, 1990; Rich et al., 2010) to test whether managerial influence tactics affect employee turnover and whether employee emotional engagement mediates this relationship. The current research provides support for the prevailing folk wisdom that employees leave managers and identifies specific behaviors that clarify how managers affect employee turnover. Our results supported our hypotheses that managerial use of pressure tactics was positively associated with employee turnover and that inspirational appeals were 
negatively associated with turnover. Furthermore, we found that emotional engagement mediated the relationship between these two types of influence tactics and employee turnover, over and above job satisfaction when job satisfaction was additionally included as a mediator in our analyses.

\section{Theoretical Implications}

We advance the scholarly literature in several key ways. First, we expand prior work on managerial determinants of turnover. Our findings draw attention to the importance of managerial influence tactics on employees' decisions to quit. To date, turnover research has predominantly focused on perceptions such as overall relationship quality between leaders and followers (e.g., LMX; Dulebohn et al., 2012; Rubenstein et al., 2017) or satisfaction with leaders (Griffeth et al., 2000) rather than on particular managerial behaviors designed to encourage employee behavior toward meeting organizational objectives. Specifically, scholars have not considered if these managerial behaviors impact whether employees stay or leave their organization. Our results suggest that inspirational appeals may contribute to employee loyalty through increased emotional engagement, while also suggesting that when managers use hard pressure tactics to control employee behavior, employees may leave. Thus, when employees cite their managers as the primary reason for leaving an organization, this attribution may be specifically related to their managers' use of pressure tactics and other abusive or disrespectful actions. In short, how managers choose to influence employees to perform may affect employees' decision to participate in an organization (i.e., stay or leave; March \& Simon, 1958), sustaining emerging formulations integrating heretofore dissociated models of organizational participation and performance (Hom, Mitchell, Lee, \& Griffeth, 2012; Meyer, Becker, \& Vandenberghe, 2004).

Second, we add to the growing research stream on job engagement by looking at emotional engagement as a key mediating mechanism explaining how and why two managerial influence tactics may affect employees' decisions to quit. By introducing the affective motivational mechanism of engagement, we more fully elucidate how managerial behaviors can drive loyalty (Lee \& Mitchell, 1994) beyond the attitudinal mechanism (i.e., job attitudes) historically promulgated by conventional turnover perspectives (Hom et al., 2017). After all, managers are "architects of context" (Dutton, 2003, p. 139) and their actions can shape how employees experience the workplace (Ashforth \& Rogers, 2012; Kahn, 1990). An employee's level of engagement is thus considered to be a conduit through which managerial behaviors are transmitted, and our findings suggest that this engagement plays a major role in the extent to which employees ultimately emotionally invest in or withdraw from the job (Rich et al., 2010). In doing this, we build on the work of Rich et al. (2010) by further validating job engagement as an important driver of work outcomes (namely, turnover) and reinforcing their findings that job engagement has important behavioral outcomes over and above traditionally studied attitudes, such as job satisfaction, job involvement, and intrinsic motivation.

Our study specifically extends turnover research by demonstrating that emotional engagement predicts employee retention and does so beyond what job satisfaction can predict. This is notable given the traditionally robust relationship observed between job satisfaction and turnover (Griffeth et al., 2000), which supports George and Jones's (1996) earlier finding that other affective constructs (e.g., moods) can play an essential role in explaining variance in turnover behavior. Hence, our results have important implications for turnover researchers, suggesting that other affective and motivational states should be included in future studies to better understand their role in explaining turnover behavior. 
Third, we advance research on influence tactics by investigating managers' use of two downward influence tactics and mechanisms translating their effects, thus shedding light on how these behaviors function (Higgins, Judge, \& Ferris, 2003), while answering Yukl et al.'s (2008) call to "directly probe the perceptual and motivational processes needed to explain how different tactics influence the attitudes and behaviors of target persons" (p. 618). Meta-analytic research concludes that there is no clear answer to the key question: "[W]hich influence tactics are most effective in obtaining positive work outcomes?" (Higgins et al., 2003, p. 101). Although universally effective tactics may not exist, our findings bring us closer to a more nuanced understanding of how two specific influence tactics affect behavioral outcomes by elucidating the psychological processes transmitting their effects (Yukl et al., 2008). Our findings indicate that influence tactics may affect important work outcomes such as turnover through the motivational mechanism of emotional engagement, which reinforces recent research integrating affect with influence tactics to predict leader effectiveness (cf. Griffith et al., 2015). Future work should continue to examine additional psychological mediating processes linking influence tactics to other important work outcomes such as LMX, communication styles/charisma, and leader authenticity (Griffith et al., 2015).

Finally, given that our study participants included high-level managers, our results suggest the importance of studying turnover among senior executives in the future. We explored why high-level employees voluntarily quit, as their loss is especially costly to employers - both financially (Bauer et al., 2006) and competitively (as leavers may transfer in-depth knowledge about operations, strategies, and customers to industry competitors; Gardner, 2005). Scholars have rarely examined voluntary terminations among such employees (Bauer et al., 2006; S. Jackson et al., 1991; Krishnan, 2009) despite the large role they play in determining the success of an organization and the high cost associated with replacing them if they leave. It is thus imperative to gain deeper insight into how top managers and executives shape the organizational context for their direct reports, and better understand how such effects can cascade down the corporate hierarchy to affect employees at multiple levels (Bass, Waldman, Avolio, \& Bebb, 1987; Harter et al., 2002; 2010; Ou et al., 2016).

\section{Practical Implications}

Preventing unwanted turnover is critical to organizations' success, and this is particularly true at the managerial level where skills, knowledge, and social capital are difficult to replace and might benefit industry rivals (Bauer et al., 2006; Gardner, 2005). As noted, the cost of managerial turnover can range from $90 \%$ to $200 \%$ of the individual's annual salary due to the high costs of recruitment, selection, and training (Boushey \& Glynn, 2012; Cascio, 2015). Furthermore, turnover at this level in the organizational hierarchy results in lost tacit knowledge, mentors, work routines, internal and external relationships, and overall effectiveness of the organization (Allen et al., 2010; Eckardt et al., 2014; Heavey et al., 2013; Holtom et al., 2008). A Gallup analysis of comprehensive meta-analytic and exit interview data suggest that more than $75 \%$ of the key reasons employees quit can be influenced by the manager (Robinson, 2008). Similar reports in the business press are replete with claims that employee decisions to leave companies have more to do with managers than with the company itself, yet academic research has largely failed to confirm such assertions. Given that voluntary turnover rates are now approaching full employment (Bureau of Labor Statistics, 2016; Hall, 2013), a better grasp of the managerial impact on voluntary turnover is both timely and crucial to retain valuable human capital. 
Our findings emphasize the importance of helping managers understand the crucial role they play in shaping employees' perception and experience of the local work environment, and the critical connection to quit decisions. Our study suggests that specific managerial behaviors do indeed impact employee decisions to leave or stay. Specifically, which influence tactics managers use with their employees plays a role in determining employee turnover decisions. Although practitioners and scholars have long recognized the impact of influence tactics on employee compliance, they have overlooked their long-term effects on other employee reactions (such as loyalty)-thus highlighting the importance of the current findings. Managers seeking to reduce turnover among their best talent need to pay closer attention to which influence tactics they use to lead their employees, promoting inspirational appeals and minimizing pressure tactics whenever possible. Such attention to influence tactics can produce tangible and intangible savings for the organization, as high turnover costs are avoided and valuable human capital is retained.

To apply this knowledge, organizations may educate managers on the overall impact they have on employees, and on the specific differential effects that pressure tactics and inspirational appeals have on employee engagement. For example, training and development programs should emphasize the importance of using inspirational appeals as a means of inducing employees to attain goals, while articulating the negative long-term implications of the use of pressure. To estimate how influence tactics affect turnover rates, we ran logistic regressions predicting turnover from each influence tactic and the controls (sex, tenure). According to these tests, a one-unit increase in pressure tactics is associated with a $91.1 \%$ increase in the predicted odds of voluntary turnover. A one-unit increase in inspirational appeals, however, is associated with a $68.7 \%$ decrease in the predicted odds of turnover. These results suggest, in practical terms, the detrimental effect pressure has as an influence tactic that can lead to employee emotional disengagement and ultimately precipitate costly turnover.

Putting mechanisms in place to reward inspirational appeals and hold managers accountable for consistently using pressure tactics would be especially impactful for organizations seeking to reduce manager-driven turnover. Additionally, organizations may consider practices and policies to retain their best talent by allowing high performers to separate from a problematic relationship with a manager through lateral moves or job rotations rather than separating from the organization entirely.

\section{Limitations and Future Research Directions}

Although the present study offers several strengths, such as the use of objective criterion and multisource data from participating executives at different points in times, we nonetheless acknowledge its limitations. First, the single organizational context and our modest sample size may affect generalizability of our findings. Our ideal sample size would have been over 100 respondents, but due to noncompletion of surveys, we ended up with a total of 90 respondents. Specifically, we cannot rule out the possibility that there is something unique to this company or industry driving our findings. Although we controlled for measurement error in our manifest variable path model by fixing the error variance = [1 - coefficient $\alpha] \times$ scale variance (Cole \& Preacher, 2014), it is possible that other measurement artifacts, such as transient error and scale-specific factor error, may have had an effect on the strength of relationships in the model (Le, Schmidt, Harter, \& Lauver, 2010). Future research should replicate our findings in other samples and industries, and perhaps use alternative measures of the constructs (e.g., engagement, job satisfaction) to solidify our understanding of the relationships between the focal constructs in this article. Second, due to company restrictions, we were limited in survey length. 
Therefore, we were unable to test the comparative impact of other influence tactics beyond pressure and inspirational appeals. Although our selection of pressure and inspirational appeals was informed by prior theory and research indicating that they are by far the most common downward tactics (Yukl et al., 2005), as well as their importance in generating affective responses in employees, future research should examine additional influence tactics to more fully gauge how influence tactics affect turnover. Additionally, although it was beyond the scope of the current study, future work should seek to better disentangle the psychological conditions that bring about employee perceptions of emotional engagement (Kahn, 1990). For example, it could be that meaningfulness, safety to be one's self, and availability of resources are differentially affected by manager influence tactics that would then predict engagement level and turnover intention. Finally, future work should attempt to replicate this study while simultaneously assessing manager-employee relationship quality. For example, although the effects are not large $(\rho=-0.17)$, recent meta-analytic techniques reveal that the dominant measure of manager-employee relationship quality, LMX, is a turnover predictor (Dulebohn et al., 2012). Hence, to increase confidence in our findings regarding the impact of manager influence tactics on voluntary turnover, future work should jointly consider LMX and influence tactics.

Regarding the turnover literature, researchers may examine other discrete managerial or leader behaviors as turnover antecedents. Our finding that managers' use of inspirational appeals can discourage employees from leaving may suggest that inspirational motivation, a dimension of transformational leadership, may also reduce turnover (cf. Waldman, Carter, \& Hom, 2012). Similarly, other specific leader behaviors that convey respect for employees (Rogers \& Ashforth, 2017) are worth studying as they may be viable alternatives to disrespectful pressure tactics and have a significant impact on the employee withdrawal process via emotional engagement.

\section{Conclusion}

As organizations struggle to minimize dysfunctional turnover, managers must examine their own behaviors as a contributor to talent loss and recognize that their behaviors toward employees are central to employee turnover. Our findings indicate that employee decisions to leave vary substantially depending on two influence tactics they are subjected to by their managers. Specifically, managers who inspire rather than pressure their employees are better able to retain talent in part because they create an emotional connection between their employees and their work. In the context of conventional wisdom suggesting that employees leave their managers rather than their companies, this study provides an important contribution to both management theory and practice that can help shape the specific behaviors managers use to influence their employees to stay.

\section{Declaration of Conflicting Interests}

The author(s) declared no potential conflicts of interest with respect to the research, authorship, and/or publication of this article.

\section{Funding}

The author(s) received no financial support for the research, authorship, and/or publication of this article. 


\section{References}

Allen, D. G., Bryant, P. C., Vardaman, J. M. (2010). Retaining talent: Replacing misconceptions with evidence-based strategies. Academy of Management Perspectives, May, 48-64. Google Scholar, Crossref, ISI

Ashforth, B. E. (1994). Petty tyranny in organizations. Human Relations, 47, 755-778. Google Scholar, SAGE Journals, ISI

Ashforth, B. E., Rogers, K. M. (2012). Is the employee-organization relationship misspecified? The centrality of tribes in experiencing the organization. In Shore, L. M., Shapiro, J. A. M., Tetrick, L. E. (Eds.), The employee-organization relationship: Applications for the 21st century (pp. 23-53). Philadelphia, PA: Taylor \& Francis. Google Scholar

Ballinger, G., Lehman, D., Schoorman, D. (2010). Leader-member exchange and turnover before and after succession events. Organizational Behavior and Human Decision Processes, 113, 25-36. Google Scholar, Crossref, ISI

Bass, B. M. (1985). Leadership and performance beyond expectations. New York, NY: Free Press. Google Scholar

Bass, B. M., Waldman, D. A., Avolio, B. J., Bebb, M. (1987). Transformational leadership and the falling dominoes effect. Group Organization Management, 12, 73-87. Google Scholar, SAGE Journals, ISI

Bauer, T., Erdogan, B., Liden, R., Wayne, S. (2006). A longitudinal study of the moderating role of extraversion: Leader-member exchange, performance, and turnover during new executive development. Journal of Applied Psychology, 91, 298-310. Google Scholar, Crossref, Medline, ISI

Bhattacharya, S. (2008, March). Why people quit. Business Today. Retrieved from http://www.businesstoday.in/magazine/trends/why-people-quit/story/1542.html Google Scholar

Boushey, H., Glynn, S. J. (2012, November). There are significant business costs to replacing employees. Retrieved from https://www.americanprogress.org/wpcontent/uploads/2012/11/CostofTurnover.pdf Google Scholar

Brief, A., Weiss, H. (2002). Organizational behavior: Affect in the workplace. Annual Review of Psychology, 53, 279-307. Google Scholar, Crossref, Medline, ISI

Bureau of Labor Statistics. (2016). Job openings and labor turnover survey highlights. Retrieved from http://www.bls.gov/web/jolts/jlt_labstatgraphs.pdf Google Scholar

Burris, E. R., Detert, J. R., Chiaburu, D. S. (2008). Quitting before leaving: The mediating effects of psychological attachment and detachment on voice. Journal of Applied Psychology, 93, 912-922. Google Scholar, Crossref, Medline, ISI

Burton, J., Holtom, B., Sablynski, C., Mitchell, T., Lee, T. (2010). The buffering effects of job embeddedness on negative shocks. Journal of Vocational Behavior, 76, 42-51. Google Scholar, Crossref, ISI

Byrne, B. (2012). Structural equation modeling in Mplus. New York, NY: Routledge. Google Scholar

Cascio, W. F. (2015). Managing human resources: Productivity, quality of work life, profits (10th ed.). Burr Ridge, IL: Irwin/McGraw-Hill. Google Scholar 
Chau, S. L., Dahling, J. J., Levy, P. E., Diefendorff, J. M. (2009). A predictive study of emotional labor and turnover. Journal of Organizational Behavior, 30, 1151-1163. Google Scholar, Crossref, ISI

Cole, D. A., Preacher, K. J. (2014). Manifest variable path analysis: Potentially serious and misleading consequences due to uncorrected measurement error. Psychological Methods, 18, 300-315. Google Scholar, Crossref, ISI

Cotton, J., Tuttle, J. (1986). Employee turnover: A meta-analysis and review with implications for research and theory. Academy of Management Review, 11, 55-70. Google Scholar, ISI

Dulebohn, J. H., Bommer, W. H., Liden, R. C., Brouer, R. L., Ferris, G. R. (2012). A meta-analysis of antecedents and consequences of leader-member exchange: Integrating the past with an eye toward the future. Journal of Management, 38, 1715-1759. doi:10.1177/0149206311415280 Google Scholar, SAGE Journals, ISI

Dutton, J. E. (2003). Energize your workplace: How to create and sustain high-quality connections at work. San Francisco, CA: Jossey-Bass. Google Scholar

Eckardt, R., Skaggs, B. C., Youndt, M. (2014). Turnover and knowledge loss: An examination of the differential impact of production manager and worker turnover in service and manufacturing firms. Journal of Management Studies, 51, 1025-1057. doi:10.1111/joms.12070 Google Scholar, Crossref, ISI

Falbe, C. M., Yukl, G. (1992). Consequences for managers of using single influence tactics and combinations of tactics. Academy of Management Journal, 35, 638-653. Google Scholar, Crossref, ISI

Finney, S., DiStefano, C. (2006). Non-normal and categorical data in structural equation modeling. In Hancock, G., Mueller, R. (Eds.), Structural equation modeling: A second course (pp. 269-314). Greenwich, CT: Information Age. Google Scholar

Fleishman, E. A. (1998). Patterns of leadership behavior related to employee grievances and turnover: Some post hoc reflections. Personnel Psychology, 51, 825-834. Google Scholar, Crossref, ISI

Frijda, N. H. (1986). The emotions. Cambridge, England: Cambridge University Press. Google Scholar

Gardner, T. (2005). Interfirm competition for human resources: Evidence from the software industry. Academy of Management Journal, 48, 237-256. Google Scholar, Crossref, ISI

George, J. M., Jones, G. R. (1996). The experience of work and turnover intentions: Interactive effects of value attainment, job satisfaction, and positive mood. Journal of Applied Psychology, 81, 318325. Google Scholar, Crossref, Medline, ISI

Grant, A. M., Sumanth, J. J. (2009). Mission possible? The performance of prosocially motivated employees depends on manager trustworthiness. Journal of Applied Psychology, 94, 927-944. doi:10.1037/a0014391 Google Scholar, Crossref, Medline, ISI

Greenhalgh, L. (1980). A process model of organizational turnover: The relationship with job security as a case in point. Academy of Management Review, 5, 299-303. Google Scholar

Griffeth, R., Hom, P., Gaertner, S. (2000). A meta-analysis of antecedents and correlates of employee turnover: Update, moderator tests, and research implications for the next millennium. Journal of Management, 26, 463-488. doi:10.1016/j.leaqua.2015.03.004 Google Scholar, SAGE Journals, ISI 
Griffith, J., Connelly, S., Thiel, C., Johnson, G. (2015). How outstanding leaders lead with affect: An examination of charismatic, ideological, and pragmatic leaders. Leadership Quarterly, 26, 502517. Google Scholar, Crossref, ISI

Hackman, J. R., Oldham, G. R. (1975). Development of the job diagnostic survey. Journal of Applied Psychology, 60, 159-170. Google Scholar, Crossref, ISI

Hall, A. (2013, March). "I'm outta here!" Why 2 million Americans quit every month (and 5 steps to turn the epidemic around). Forbes. Retrieved from http://www.forbes.com/sites/alanhall/2013/03/11/im-outta-here-why-2-million-americansquit-every-month-and-5-steps-to-turn-the-epidemic-around/\#512d4e20f9fe Google Scholar

Hallberg, U., Schaufeli, W. (2006). "Same same" but different? European Psychologist, 11, 119-127. Google Scholar, Crossref, ISI

Harris, K. J., Wheeler, A. R., Kacmar, K. M. (2009). Leader-member exchange and empowerment: Direct and interactive effects on job satisfaction, turnover intentions, and performance. Leadership Quarterly, 20, 371-382. Google Scholar, Crossref, ISI

Harris, T. B., Li, N., Kirkman, B. L. (2014). Leader-member exchange (LMX) in context: How LMX differentiation and $L M X$ relational separation attenuate $L M X$ 's influence on OCB and turnover intention. Leadership Quarterly, 25, 314-328. doi:10.1016/j.leaqua.2013.09.001 Google Scholar, Crossref, ISI

Harrison, D. A., Newman, D. A., Roth, P. L. (2006). How important are job attitudes? Meta-analytic comparisons of integrative behavioral outcomes and time sequences. Academy of Management Journal, 49, 305-325. Google Scholar, Crossref, ISI

Harter, J. K., Schmidt, F. L., Asplund, J. W., Killham, E. A., Agrawal, S. (2010). Causal impact of employee work perceptions on the bottom line of organizations. Perspectives on Psychological Science, 5, 378-389. Google Scholar, SAGE Journals, ISI

Harter, J. K., Schmidt, F. L., Hayes, T. L. (2002). Business-unit-level relationship between employee satisfaction, employee engagement, and business outcomes: A meta-analysis. Journal of Applied Psychology, 87, 268-279. Google Scholar, Crossref, Medline, ISI

Hayes, A. F. (2013). Introduction to mediation, moderation, and conditional process analysis. New York, NY: Guilford Press. Google Scholar

Heavey, A., Holwerda, J., Hausknecht, J. (2013). Causes and consequences of collective turnover: A meta-analytic review. Journal of Applied Psychology, 98, 412-453. doi:10.1037/a0032380 Google Scholar, Crossref, Medline, ISI

Higgins, C. A., Judge, T. A., Ferris, G. R. (2003). Influence tactics and work outcomes: A meta-analysis. Journal of Organizational Behavior, 24, 89-106. Google Scholar, Crossref, ISI

Holtom, B. C., Mitchell, T. R., Lee, T. W., Eberly, M. B. (2008). Turnover and retention research: A glance at the past, a closer review of the present, and a venture into the future. Academy of Management Annals, 2, 231-274. Google Scholar, Crossref, ISI

Hom, P. W., Kinicki, A. J. (2001). Toward a greater understanding of how dissatisfaction drives employee turnover. Academy of Management Journal, 44, 975-987. Google Scholar, Crossref, ISI 
Hom, P. W., Lee, T., Shaw, J., Hausknecht, J. (2017). Seminal research in turnover during the past 100 years. Journal of Applied Psychology, 102, 530-545. doi:10.1037/apl0000103 Google Scholar, Crossref, Medline, ISI

Hom, P. W., Mitchell, T. R., Lee, T. W., Griffeth, R. W. (2012). Reviewing employee turnover: focusing on proximal withdrawal states and an expanded criterion. Psychological Bulletin, 138, 831-858. Google Scholar, Crossref, Medline, ISI

Hom, P. W., Roberson, L., Ellis, A. (2008). Challenging conventional wisdom about who quits: Revelations about employee turnover from corporate America. Journal of Applied Psychology, 93, 1-34. Google Scholar, Crossref, Medline, ISI

Hu, L. T., Bentler, P. M. (1999). Cutoff criteria for fit indexes in covariance structure analysis: Conventional criteria versus new alternatives. Structural Equation Modeling: A Multidisciplinary Journal, 6, 1-55. Google Scholar, Crossref, ISI

Jackson, E. (2014, May). The top 8 reasons your best people are about to quit and how you can keep them. Retrieved from http://www.forbes.com/sites/ericjackson/2014/05/11/the-top-8-reasonsyour-best-people-are-about-to-quit-and-how-you-can-keep-them/\#12a43731719b Google Scholar

Jackson, S., Brett, J., Sessa, V., Cooper, D., Julian, J., Peyronnin, K. (1991). Some differences make a difference: Individual dissimilarity and group heterogeneity as correlates of recruitment, promotions, and turnover. Journal of Applied Psychology, 76, 675-689. Google Scholar, Crossref, $|S|$

Judge, T. A., Piccolo, R. F., Ilies, R. (2004). The forgotten ones? The validity of consideration and initiating structure in leadership research. Journal of Applied Psychology, 89, 36-51. Google Scholar, Crossref, Medline, ISI

Judge, T. A., Weiss, H. M., Kammeyer-Mueller, J. D., Hulin, C. L. (2017). Job attitudes, job satisfaction, and job affect: A century of continuity and of change. Journal of Applied Psychology, 102, 356374. doi:10.1037/apl0000181 Google Scholar, Crossref, Medline, ISI

Kahn, W. A. (1990). Psychological conditions of personal engagement and disengagement at work. Academy of Management Journal, 33, 692-724. Google Scholar, Crossref, ISI

Kahn, W. A. (1992). To be fully there: Psychological presence at work. Human Relations, 45, 321-349. Google Scholar, SAGE Journals, ISI

Kipnis, D., Schmidt, S., Wilkinson, I. (1980). Intraorganizational influence tactics: Explorations in getting one's way. Journal of Applied Psychology, 65, 440-452. Google Scholar, Crossref, ISI

Kline, R. B. (2011). Principles and practices of structural equation modeling (3rd ed.). New York, NY: Guilford Press. Google Scholar

Krishnan, H. (2009). What causes turnover among women on top management teams? Journal of Business Research, 62, 1181-1186. Google Scholar, Crossref, ISI

Lapointe, E., Vandenberghe, C., Panaccio, A. (2011). Organizational commitment, organization-based self-esteem, emotional exhaustion and turnover: A conservation of resources perspective. Human Relations, 64, 1609-1631. doi:10.1177/0018726711424229 Google Scholar, SAGE Journals, ISI 
Le, H., Schmidt, F. L., Harter, J. K., Lauver, K. J. (2010). The problem of empirical redundancy of constructs in organizational research: An empirical investigation. Organizational Behavior and Human Decision Processes, 112, 112-125. Google Scholar, Crossref, ISI

Lee, T. W., Mitchell, T. R. (1994). An alternative approach: The unfolding model of voluntary employee turnover. Academy of Management Review, 19, 51-89. Google Scholar, ISI

Lee, T. W., Mitchell, T. R., Holtom, B. C., McDaniel, L., Hill, J. W. (1999). Theoretical development and extension of the unfolding model of voluntary turnover. Academy of Management Journal, 42, 450-462. Google Scholar, Crossref, ISI

Lee, T. W., Mitchell, T. R., Wise, L., Fireman, S. (1996). An unfolding model of voluntary employee turnover. Academy of Management Journal, 39, 5-36. Google Scholar, Crossref, ISI

Locke, E. (1976). The nature and causes of job satisfaction. In Dunnette, M. D. (Ed.), Handbook of industrial and organizational psychology (pp. 1297-1350). Chicago, IL: Rand McNally. Google Scholar

Maas, C. J. M., Hox, J. J. (2005). Sufficient sample sizes for multilevel modeling. Methodology, 1, 86-92. Google Scholar, Crossref

MacKinnon, D., Lockwood, C., Hoffman, J., West, S., Sheets, V. (2002). A comparison of methods to test mediation and other intervening variable effects. Psychological Methods, 7, 83-104. Google Scholar, Crossref, Medline, ISI

March, J. G., Simon, H. A. (1958). Organizations. New York, NY: Wiley. Google Scholar

McEvoy, G. M., Cascio, W. F. (1985). Strategies for reducing employee turnover: A meta-analysis. Journal of Applied Psychology, 70, 342-353. Google Scholar, Crossref, ISI

Meyer, J. P., Becker, T. E., Vandenberghe, C. (2004). Employee commitment and motivation: A conceptual analysis and integrative model. Journal of Applied Psychology, 89, 991-1007. Google Scholar, Crossref, Medline, ISI

Mitchell, T., Lee, T. (2001). The unfolding model of voluntary turnover and job embeddedness: Foundations for a comprehensive theory of attachment. Research in Organizational Behavior, 23, 189-246. Google Scholar, Crossref, ISI

Mobley, W. H., Griffeth, R.W., Hand, H. H., Meglino, B. M. (1979). Review and conceptual analysis of the employee turnover process. Psychological Bulletin, 86, 493-522. Google Scholar, Crossref, ISI

Muthén, L., Muthén, B. (2012). Mplus Version 7. Los Angeles, CA: Muthén \& Muthén. Google Scholar

Ou, A., Seo, J., Choi, D., Hom, P. (2016). When can humble top executives retain middle managers? The moderating role of top management team faultlines. Academy of Management Journal. Advance online publication. doi:10.5465/amj.2015.1072 Google Scholar, Crossref, ISI

Pearson, C. M., Porath, C. L. (2005). On the nature, consequences, and remedies of workplace incivility: No time for "nice"? Think again. Academy of Management Executive, 19, 7-18. Google Scholar

Preacher, K. J., Hayes, A. F. (2008). Asymptotic and resampling strategies for assessing and comparing indirect effects in multiple mediator models. Behavior Research Methods, 40, 879-891. Google Scholar, Crossref, Medline, ISI 
Podsakoff, P. M., MacKenzie, S. B., Lee, J. Y., Podsakoff, N. P. (2003). Common method biases in behavioral research: A critical review of the literature and recommended remedies. Journal of Applied Psychology, 88, 879-903. Google Scholar, Crossref, Medline, ISI

Price, J. L., Mueller, C. W. (1986). Absenteeism and turnover of hospital employees. Greenwich, CT: JAI Press. Google Scholar

Rich, B. L., LePine, J. A., Crawford, E. R. (2010). Job engagement: Antecedents and effects on job performance. Academy of Management Journal, 53, 617-635. Google Scholar, Crossref, ISI

Robinson, J. (2008, May 8). Turning around employee turnover. Gallup Business Journal. Retrieved form http://www.gallup.com/businessjournal/106912/Turning-Around-Your-TurnoverProblem.aspx Google Scholar

Rogers, K. M, Ashforth, B. E. (2017). Respect in organizations: Feeling valued as "me" and "we". Journal of Management, 43, 1578-1608. doi:10.1177/0149206314557159 Google Scholar, SAGE Journals, ISI

Rubenstein, A. L., Eberly, M. B., Lee, T. W., Mitchell, T. R. (2017). Surveying the forest: A meta-analysis, moderator investigation, and future-oriented discussion of the antecedents of voluntary employee turnover. Personnel Psychology. Advance online publication. doi:10.1111/peps.12226 Google Scholar, Crossref, ISI

Rusbult, C. E., Farrell, D. (1983). A longitudinal test of the investment model: The impact on job satisfaction, job commitment, and turnover of variations in rewards, costs, alternatives, and investments. Journal of Applied Psychology, 68, 429-438. Google Scholar, Crossref, ISI

Russell, S. S., Spitzmüller, C., Lin, L. F., Stanton, J. M., Smith, P. C., Ironson, G. H. (2004). Shorter can also be better: The abridged job in general scale. Educational and Psychological Measurement, 64, 878-893. Google Scholar, SAGE Journals, ISI

Russell, S. S., Stone, A. G. (2002). A review of servant leadership attributes: Developing a practical model. Leadership \& Organization Development Journal, 23, 145-157. Google Scholar, Crossref

Salancik, G. R., Pfeffer, J. (1978). A social information processing approach to job attitudes and task design'. Administrative Science Quarterly, 23, 224-253. Google Scholar, Crossref, Medline, ISI

Scherbaum, C. A., Ferreter, J. M. (2009). Estimating statistical power and required sample sizes for organizational research using multilevel modeling. Organizational Research Methods, 12, 347367. Google Scholar, SAGE Journals, ISI

Schyns, B., Schilling, J. (2013). How bad are the effects of bad leaders? A meta-analysis of destructive leadership and its outcomes. Leadership Quarterly, 24, 138-158. doi:10.1016/j.leaqua.2012.09.001 Google Scholar, Crossref, ISI

Sparrowe, R. T., Soetjipto, B. W., Kraimer, M. L. (2006). Do leaders' influence tactics relate to members' helping behavior? It depends on the quality of the relationship. Academy of Management Journal, 49, 1194-1208. Google Scholar, Crossref, ISI

Survey: Bad managers why employees leave. (2009). American Agent \& Broker, 81(3), 7. Google Scholar

Ulrich, D., Smallwood, N. (2006). How leaders build value: Using people, organization, and other intangibles to get bottom-line results. Englewood Cliffs, NJ: Wiley. Google Scholar 
Waldman, D. A., Carter, M. Z., Hom, P. W. (2012). A multi-level investigation of leadership and turnover behavior. Journal of Management, 41, 1724-1744. doi:10.1177/0149206312460679 Google Scholar, SAGE Journals, ISI

Wright, T. A., Cropanzano, R. (1998). Emotional exhaustion as a predictor of job performance and voluntary turnover. Journal of Applied Psychology, 83, 486-493. Google Scholar, Crossref, Medline, ISI

Wrzesniewski, A., Dutton, J. (2001). Crafting a job: Revisioning employees as active crafters of their work. Academy of Management Review, 26, 179-201. Google Scholar, ISI

Yu, C. Y. (2002). Evaluating cutoff criteria of model fit indices for latent variable models with binary and continuous outcomes (Doctoral dissertation). Retrieved from https://www.statmodel.com/download/Yudissertation.pdf Google Scholar

Yukl, G. (2010). Leadership in organizations. Englewood Cliffs, NJ: Prentice-Hall. Google Scholar

Yukl, G., Chavez, C., Seifert, C. F. (2005). Assessing the construct validity and utility of two new influence tactics. Journal of Organizational Behavior, 26, 705-725. Google Scholar, Crossref, ISI

Yukl, G., Falbe, C. M. (1990). Influence tactics in upward, downward, and lateral influence attempts. Journal of Applied Psychology, 75, 132-140. Google Scholar, Crossref, ISI

Yukl, G., Kim, H., Falbe, C. M. (1996). Antecedents of influence outcomes. Journal of Applied Psychology, 81, 309-317. Google Scholar, Crossref, ISI

Yukl, G., Seifert, C. F., Chavez, C. (2008). Validation of the extended Influence Behavior Questionnaire. Leadership Quarterly, 19, 609-621. Google Scholar, Crossref, ISI

Yukl, G., Tracey, J. B. (1992). Consequences of influence tactics used with subordinates, peers, and the boss. Journal of Applied Psychology, 77, 525-535. Google Scholar, Crossref, ISI

Zellars, K., Tepper, B., Duffy, M. (2002). Abusive supervision and subordinates' organizational citizenship behavior. Journal of Applied Psychology, 87, 1068-1076. Google Scholar, Crossref, Medline, ISI

\section{Author Biographies}

Christopher S. Reina is an assistant professor in the Department of Management at Virginia Commonwealth University. He received his PhD in business administration (management) from the W. P. Carey School of Business at Arizona State University. His research focuses on the intersection of leadership, mindfulness, and emotions in the workplace and how they facilitate employee engagement, performance, and well-being.

Kristie M. Rogers is an assistant professor in the management department at Marquette University. She received her PhD in business administration (management) from the W. P. Carey School of Business at Arizona State University. Her research focuses on the topics of respect, identity, and stigma in organizations.

Suzanne J. Peterson is an associate professor at Arizona State University's Thunderbird School of Global Management. She received her PhD from the University of Nebraska at Lincoln. Her current research interests include CEO leadership, women on boards, and drivers of high performance in individuals, groups, and firms. 
Kris Byron is an associate professor of managerial sciences at the J. Mack Robinson College of Business, Georgia State University, where she also received her PhD. Her primary research interests are emotion, creativity, self-regulation, and gender. She presently serves on the executive committee of the Research Methods Division of the Academy of Management and as associate editor of the Academy of Management Review.

Peter W. Hom is a professor of Management at the WP Carey School of Business, Arizona State University. He received his PhD from the University of Illinois. He has developed and tested theories of employee turnover and designed realistic job previews to reduce reality shock. He serves on Editorial Boards for the Journal of Applied Psychology, Academy of Management Journal, and Journal of Management. 